\title{
Jens Jessen, børnene og børnebladet
}

Af Poul Kürstein.

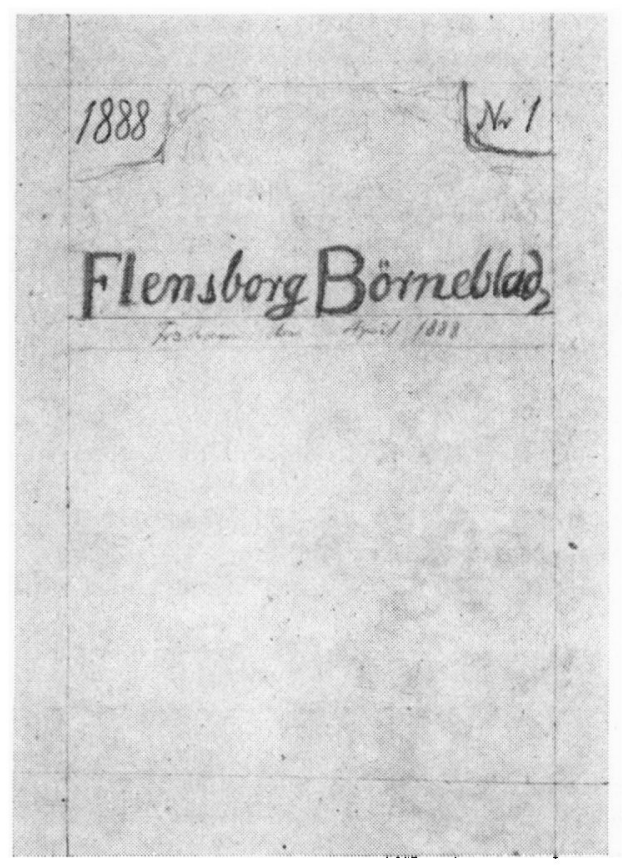

Jessens udkast til Flensborg Borneblad.

Holderne af Flensborg Avis fik noget for deres penge.

Udover den daglige avis seks gange om ugen fik de om lordagen Nordslesvigsk Søndagsblad, både Folkelig Del og Kirkelig Del. Søndagsbladet var groet frem af bladets eget søndagstillæg, og også Børneblad til Flensborg Avis, der ligesom søndagsbladet var et $f \mathfrak{l}$ lesforetagende for de sønderjyske aviser, skyldte i høj grad Flensborg Avis sin fortsatte eksistens. Fra nytår 1905 fulgte børnebladet med avisen, men også før den tid var det muligt at få et særligt dansk børneblad i Sønderjylland. 
Ved sprogforordningen af 1888 bandlyste projserne undervisningen i modersmålet fra skolen, og Nordslesvigsk Søndagsblad gik da i 1889 over til at bringe en særskilt afdeling for ungdommen. Men allerede $\mathrm{i}$ de første måneder af 1888 , altså for sprogforordningen, havde Jens Jessen tænkt på det brændende spørgsmål om særlig læsning for børnene. Endnu mens han sad i frengslet i Glïckstadt, som løslod ham den 4. april, havde han lavet det udkast til hoved og fod af Flensborg Børneblad, som endnu gemmes i Flensborg Avis' arkiv. Hovedet så sådan ud:

\section{FLENSBORG BØRNEBLAD $1888 \quad \mathrm{Nr} .1$ Fredagen den .... April 1888}

og foden havde denne ordlyd:

»Flensborg Børneblad udgaar en Gang om Ugen og koster, bestilt paa et tysk Postkontor, $16 \mathrm{Pg}$ foruden Postpenge $4 \mathrm{Pg}$ og (ulæseligt) hvert Fjerdingaar. Bestilt paa et kongerigsk Postkontor koster Bladet 26 Øre Fjerdingaaret «.

Dette børneblad blev dog ikke til noget, men i 1889 trykte Jens Jessen i Flensborg Avis sin navnkundige $A B C$, som udkom som særlig bog med titlen "Flensborg Avis' Stavebog for Hjemmet $\alpha$ i alt i 14.000 eksemplarer. Fra samme år er hans ${ }^{2}$ Sønderjysk Sangbog for Børn «, som var lige så vigtig, og som ligeledes fulgte avisen. Den blev trykt i 10.000 eksemplarer i alt.

I 1892 fik den særlige udgave af Nordslesvigsk Søndagsblad, som Jens Jessen udgav under titlen Flensborg Ugeblad et tillæg: Flensborg Ugeblad for Bern. Det fik dog kun en stakket tid at leve i, nemlig 1 år. Også det tænkte han på, da han i 1893 sad i fængsel i Flensborg, for her digtede han 16 småvers på hver fire linjer som disse:

\section{Uden for vort buses mur sidder missekat på lur, men den lille kloge mus smutter rask ind $i$ vort bus.}

Her svigtede vist nok kræfterne, men viljen bør da påskønnes. ${ }^{1}$

I mellemtiden havde man andet steds fundet frem til en bedre løsning på det brændende spørgsmål: hvorledes kunne man størte hjemmenes undervisning $i$ modersmålet ved lasning egnet for børn. 
Bogtrykker Konrad Jørgensen i Kolding, grundlæggeren af Højskolebladet, havde siden 1877 trykt og udgivet Børnenes Blad. Til Lxsning i Hjemmet og Skolen. Fra 1887 blev det udgivet af den gode folkelige forfatter Jens Skytte, som uden at være lærer dog står som et godt eksempel på »skolelærerlitteraturen «.

Dette blad fik fra 1889-90 - og dette tidspunkt er jo ikke tilfældigt - undertitlen Illustreret Børneblad for Nordslesvig. Det havde fortsat Jens Skytte som redaktør, men M. Andresen, Sprogforeningens sekretær, stod som udgiver og Ảbenrå som udgivelsessted. Dog blev det som tidligere trykt i Kolding hos Konrad Jørgensen. Ved siden af den sønderjyske udgave løb der en udgave for kongeriget: Børnenes Blad, som dog gik ind i 1898.

Andresen udgav bladet til 1900, da Thade Petersen overtog ansvaret. Den senere frimenighedspræst i Haderslev var på dette tidspunkt Hejmdals lokalredaktør i Rødding. Bladet blev i Sønderjylland solgt for 35 øre fjerdingåret eller rettere sagt: for det tilsvarende antal penninge. I 1901 kostede det 25 penning foruden postpenge. Det udkom til og med 1903, da det måtte gå ind, vel sagtens fordi det lige som den kongerigske udgave ikke havde en tilstrækkelig indtrgt fra holderne.

Det var Jens Jessen, som fik det $\mathrm{i}$ gang igen. Allerede $\mathrm{i}$ december 1902 omtalte han sine planer med Illustreret Børneblad overfor direktør N. Bang." Inden oktober 1903 talte han om sagen på et møde i København, og her nævnede han, at han manglede $500 \mathrm{kr}$. Dem fik han af tre sjxllandske godsejere. Den 29. og 30. november 1903 deltog han $\mathrm{i}$ " forårsmødet “, som dog dette år var henlagt til efteråret, og som blev holdt af de samvirkende sønderjyske foreningers fællesudvalg i samarbejde med førende mænd fra Sønderjylland. Børnebladet var sat på dagsordenen - Jessen havde mindet overretssagfører Ove Krarup om dette emne den 22. november - og bladets udgiver Thade Petersen var indbudt til mødet. Fællesudvalget tog vare på de opgaver, som senere Grænseforeningen tog sig af, og på dette møde må der være bevilget de nødvendige midler.

At Jessen var den drivende kraft, ses af, at planens praktiske udførelse lå $\mathrm{i}$ hans hånd. I juni 1904, den 10. eller 11., var der et møde på Jessens sommerhus Fjordmark $\mathrm{i}$ Kollund af en tremandskommission, som bestod af H. Thomsen (Roost), sekretær for Skoleforeningen, M. Andresen for Sprogforeningen og Jens Jessen selv. Allerede 


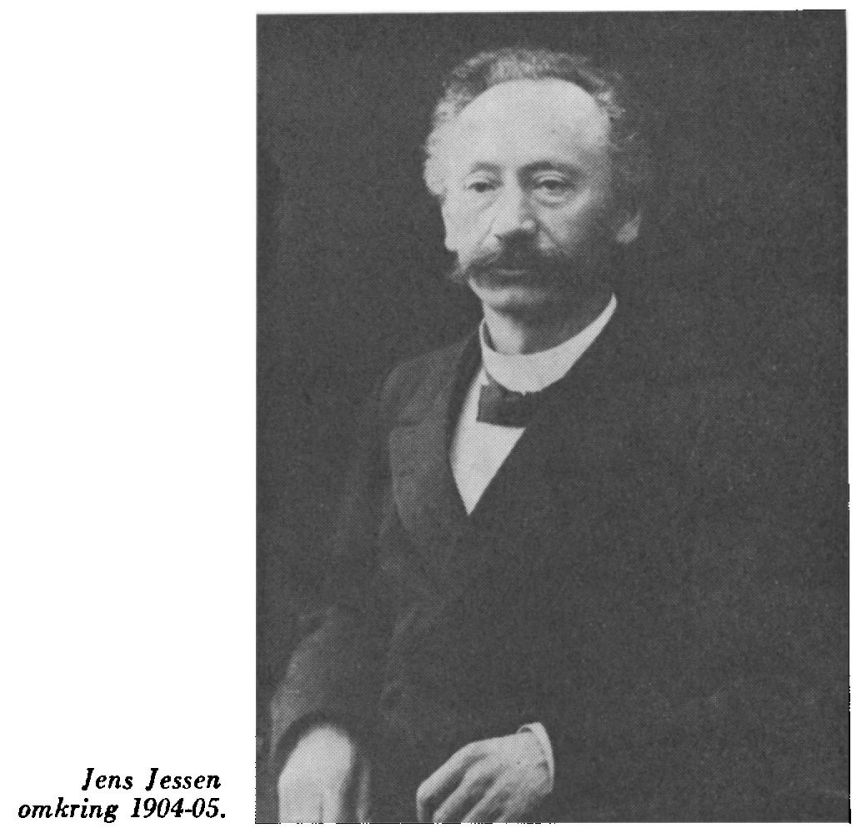

den 9. eller 10. juli kender han trykomkostninger for 16.000 eksemplarer, og hvad bladene skal give for dem. Den 22. juli var skoleinspektør H. P. Hansen og overretssagfører Ove Krarup med hustruer »i xrterne« på Fjordmark, og J. P. Reimers og Johannes Moldt, redaktøren af Dybbøl-Posten, gxestede Jessen den 10 . august. Ved begge lejligheder har man nok snakket børneblad, som måtte interessere alle de næunte, og den middag, som $\mathrm{H}$. Thomsen, Roost, indbød Jens Jessen til i Haderslev 9. juli har ikke kun skullet glæde ganen og mætte maven. Jens Jessen var ingen middagsherre. I september 1904 tiltrådte Johannes Moldt på Dybbøl-Postens vegne cg Nicolai Svendsen for Dannevirke overenskomsten om udgivelse af et fxlles børneblad. Jens Jessen havde allerede da drøftet trykningen med Konrad Jørgensen og talt med Jens Skytte, der gæstede ham på Fjordmark, om indholdet af bladet, som Jens Jessen ønskede ud allerede 1 . oktober 1904, da den erfarne bladmand vidste, at dette tidspunkt er det bedste til start af et nyt blad. Af mangel på papir kunne Jørgensen dog først love første nummer ud til nytår 1905. Den 17. september gjorde Jens Jessen notater om prisen på klicheer til det nye blad, og nu var han klar til det afgørende møde. 


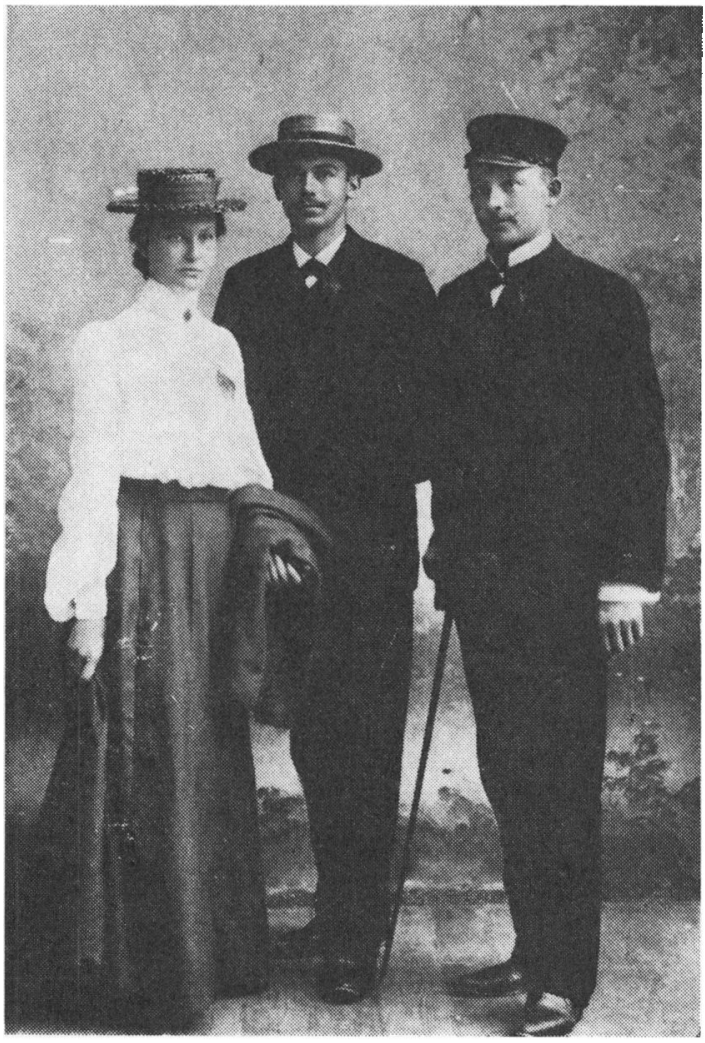

Kathrine Svensson, f. Billum.

frimenighedsprost Jorgen Eriksen og A. Svensson kort efter Svenssons bryllup 11. maj 1905.

Det blev holdt 16. oktober 1904 på "Harmonien « i Haderslev. I mødet deltog professor C. Nyrop. Han var sammen med skoleinspektør H. P. Hansen og overretssagfører Ove Krarup talsmand for det kongerigske fællesudvalg, men de to sidste nævnes ikke som tilstedeværende. De danske blade Dannevirke og Dybbøl-Posten var repræsenteret, og landdagsmand $\mathrm{H}$. P. Hanssen var mødt for Hejmdal. Konrad Jørgensen, der fortsat skulle trykke bladet, blev tilkaldt.

For et børneblad på 8 sider i kvartformat skulle de fire samarbejdende blade betale Konrad Jørgensen 3 penning pr. eksemplar for fjerdingåret, altså 12 penning om året. Konrad Jørgensens trykpris pr. årligt eksemplar var 52 øre. Forskellen blev dækket af tilskud. Oplaget skulle være: Flensborg Avis 8000, Hejmdal 3500, Dannevirke 3000 og Dybbøl-Posten 800 , i alt 15.300 . I disse tal er ind- 
L. P. Christensen omkring 1905.

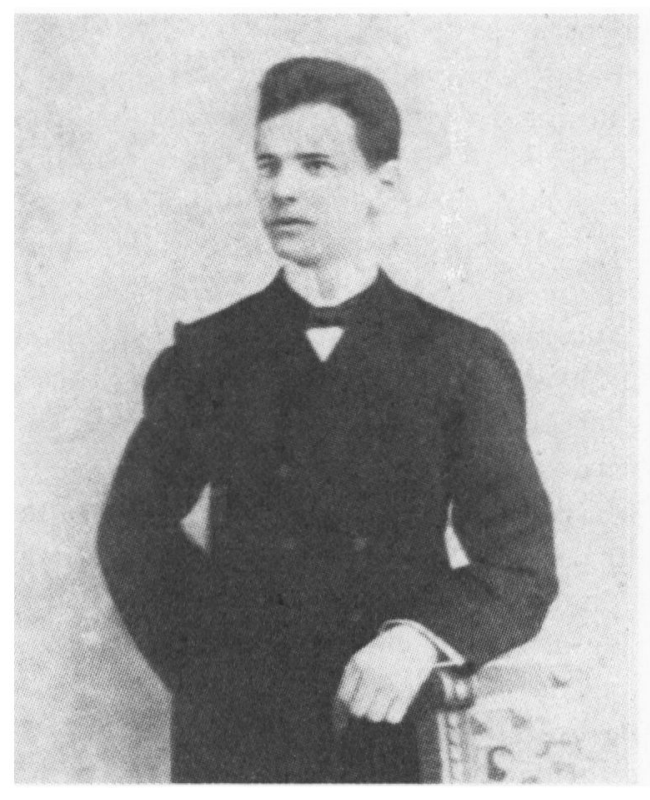

regnet oplaget af de nævnte hovedblades særudgaver, altså for Flensborg Avis' vedkommende også Vestslesvigs Tidende, Flensborg Avis. Mindre Udgave og Flensborg Avis. Mindste Udgave.

Bladet udkom hver anden uge, og det meget store oplag gjorde børnebladet til det mest udbredte blad i Sønderjylland, ja det var endda mere udbredt end det andet fxllesforetagende Nordslesvigsk Søndagsblad, som ikke fulgte med Hejmdal, og det store oplag medførte en meget lav trykpris, men uden de tilskud fra kongeriget, som Jens Jessen havde skaffet, ville bladet næppe være kommet ud. Det nye for holderne var, at de nu fik børnebladet gratis sammen med deres dagblad. Jens Jessens udpragede sans for praktisk bladdrift kom også frem her, idet han ønskede sine eksemplarer af børnebladet falset 1 gang $i$ stedet for 2 gange. Derved kunne bernebladet lettere lægges ind i Flensborg Avis, der jo var falset 2 gange, og også blive der under postforsendelsen og udbæringen.

På mødet i Haderslev havde man talt om at få en fælles ansvarshavende redaktør i Sønderjylland, som helst skulle holdes uden løn. Dette påtog Jens Jessen sig at skaffe, hvortil alle sagde: "Godt«, 
mens ingen - heller ikke H. P. Hanssen - sagde imod. Først i januar 1905 krævede Hejmdals redaktør A. Lebeck imidlertid med tilslutning fra $\mathrm{H}$. P. Hanssen og M. Andresen, at Hejmdals udgave skulle have sin egen redaktør, nemlig Thade Petersen. Jens Jessen fastholdt $\sin$ ret til at udnævne en fælles redaktor og mente, at Hejmdal højst kunne ønske at få sit eget forlag angivet på sit oplag, men "jeg har derfor foreslået, at hr. Svensson skulle stå som »ansvarshavende for redaktion og forlag «, hvad der også ville være praktisk af den grund, at til eksempel optryk af et nationalt digt eventuelt ville kunne give anledning til anklage mod alle forlæggerne, hvis der var flere af dem «.

Disse ord var en lektion i så elementær pressejura, at den må have været pinlig at modtage for ellers erfarne pressemænd. Jens Jessen kunne have henvist til, at de andre fællesblade: Nordslesvigsk Søndagsblad. Folkelig Del og Nordslesvigsk Søndagsblad. Kirkelig Del kun havde én ansvarlig redaktør og én ansvarlig udgiver. Han kunne også have peget på, at netop Nordslesvigsk Søndagsblad havde erfaring for, hvor farligt det var at have flere udgivere og redaktører. 13. marts 1879 meddelte Flensborg Avis, at der var indledt en retssag for majestætsfornærmelse mod søndagsbladets ansvarlige redaktør A. C. C. Holdt og bladets forlægger Gustav Johannsen, men også Chr. F. Monrad og redaktør M. Grünwald ved Dannevirke og forlæggeren af Dybbøl-Posten Hans Lassen blev inddraget i sagen. Hvis denne sag havde fået fremgang, kunne hele den sønderjyske presse være blevet lammet med ét slag.

Også Konrad Jørgensen modsatte sig bestemt at få fire redaktører, da det ville bringe korrektur $\mathrm{m}$. $\mathrm{m}$. $\mathrm{i}$ vild uorden.

Få dage efter var H. P. Hanssen i Berlin som landdagsmand. Her mødte han rigsdagsmand Jens Jessen, og de må have talt sig til rette. Jens Jessen fik sin vilje, men Ảbenrå-folkene fik også delvis deres, for Jessen måtte lade Svensson falde efter de første to numre. I hans sted blev L. P. Christensen "ansvarshavende for redaktion og for$\operatorname{lag} \kappa_{0}^{3}$

I denne sag skal man næppe søge nogen egentlig modsætning mellem H. P. Hanssen og Jens Jessen. Snarere var det et forsøg fra Lebecks side på at skaffe oprejsning til Hejmdal-manden Thade Petersen, børnebladets tidligere redaktør. Der ligger heller ikke noget særligt $i$, at Jens Jessen udpegede Svensson, for Jessen havde som 
grundsæetning at lade sine medarbejdere komme til ansvar efter aldersfølge. Peter Simonsen var ansvarlig for »Verdens Gang«. Ernst Christiansen havde et stort ansvar som redaktionssekretær. Børnebladet skulle nu overlades til Svenssons evner, som Jessen havde stor tillid til. I stedet for blev det den næste i rækken, L. P. Christensen. Hans myreflid, store arbejdskraft, pålidelighed og evne til omhu for hverv, han påtog sig, kendte Jessen ikke bare fra avisen, men også fra rosenhaven på Fjordmark. Jens Jessen granskede nøje sine folk.

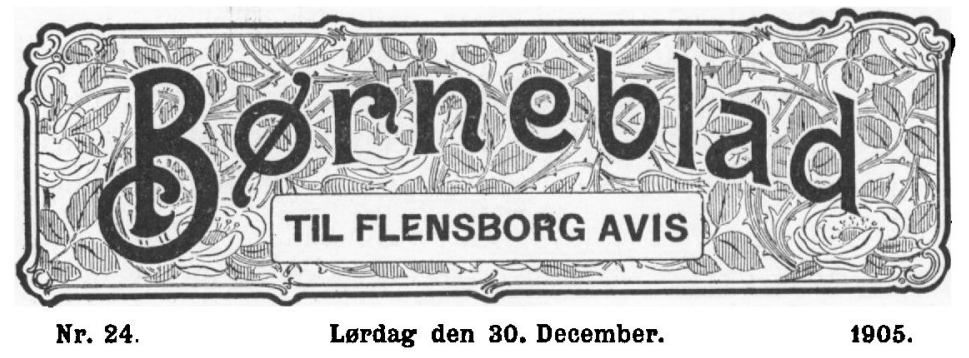

Endnu samme forår gav Jessen den vragede Svensson fuld oprejsning. Med udgangen af marts 1905 forlod Helga Skrumsager Nordslesvigsk Søndagsblad. Folkelig Del, og Svensson overtog redaktionen. Helga Skrumsagers tid er højdepunktet i dette fortrinlige tidsskrifts historie, og at følge efter hende var yderst krævende, men Svenssons grundige kendskab til litteratur, fine forståelse af bøger og hans dygtighed som pressemand førte med sig, at søndagsbladet blev oppe på højden $\mathrm{i}$ hele hans tid som redaktør.

L. P. Christensens opgave som slesvigsk redaktør af børnebladet var at se korrekturtrykket igennem for at sikre, at indholdet ikke gav de tyske domstole mulighed for at rejse straffesager. Det kunne kun en prøvet pressemand i selve Sønderjylland skønne over. Han skulle desuden føre brevvekslingen og samarbejde med studenterforeningen »Heimdal « om præmiestilene.

Bladet skiftede hoved. Titlen »Børneblad« var omgivet af et smukt bladranke-motiv, og heri var der udsparet plads til undertitlerne: »til Flensborg Avis«, »til Hejmdal «, »til Dannevirke« samt »til Dybbøl-Posten «. Det sidstnævnte blad trak sig dog tilbage i 1915, da A. Svensson var blevet indkaldt. Bladets indtægter svigtede, 
og det evnede ikke at betale 96 mark om året for 800 eksemplarer af børnebladet. Det blev ikke bedre siden, da samarbejdet med Hejmdal var ved at tage livet af det.

L. P. Christensen var ansvarshavende for redaktion og forlag, lige til han blev indkaldt $i$ 1915. Endnu for nummeret den 30. juni 1915 står hans navn på foden af sidste side, men fra næste nummer den 15. juli 1915 har P. Simonsen overtaget ansvaret, og det vedblev han at have, lige til bladet gik ind ved udgangen af 1917.

Bladet var $\mathrm{i}$ udstyr, papir og format lige til det sidste på højde med sig selv, men fra april 1917 kom der kun ét nummer hver måned $i$ stedet for to, og til sidst måtte Konrad Jørgensen frasige sig trykningen, da vanskelighederne ved at fremstille børnebladet til en rimelig pris var blevet for store. Og når han ikke kunne, var heller ingen anden $\mathrm{i}$ stand til det. Han har nxppe sat til på det, men fortjenesten har sikkert været så lille, at der skulle en ikke ringe ide.alisme til.

Det var altså dyrtiden i kongeriget og ikke de meget store vanskeligheder i Sønderjylland, der gjorde det af med børnebladet. I 1917 var Simonsen sammen med Andreas Grau og Augusta Nielsen ene om at slabe Flensborg Avis gennem den stadigt vanskeligere hverdag, men medens Nordslesvigsk Søndagsblad på samme tid blev mere og mere kedeligt og ensformigt, var der intet at mærke på børnebladet, lige som det havde været sig selv ligt også gennem de tidligere redaktørskift. Det skyldes, at det egentlige redaktionsarbejde såvel som korrekturlæsningen hele tiden blev gjort i Kolding, og det var Konrad Jørgensen og sxrlig Jens Skytte, der trak læsset. Konrad Jørgensen havde som redaktør og udgiver af Højskolebladet de forbindelser til forfattere og tegnere, som var nødvendige og nyttige. Både han og Skytte har også i stort omfang præget bladet ved talrige bidrag.

Bladets tekst var en meget afvekslende blanding af morsomme eller rørende smådigte, historier og oplysende bidrag, ikke mindst fra fædrelandets historie. Men der gxlder det samme for børnebladet som for søndagsbladet, at dets sønderjyske sigte ikke tyngede bladet i særlig grad. Der var ikke mere sønderjysk stof $i$ det end $i$ andre af samtidens nationalt bevidste blade og tidsskrifter. Hovedsagen for udgiverne var jo også overhovedet at skaffe dansk læesning ind i hjemmet til de sønderjyske børn. Men husker man baggrunden for bladets særlige sønderjyske opgave, sprogforordningen af 1888 , læg- 


\section{Til Børnebladets Læsere i Nordslesvig.}

1) Bladets Ledelse som Gave har modtaget en stor Mæengde Bøger, beder den dem, der gerne vil have én, om at skrive en Stil om:

\section{"Mit Kjem".}

Alle de, der gor sig al mulig Umag med at skrive Stilen, vil da senere faa en Bog tilsendt.

Det er dog ubetinget nodvendigl, at der efter Stilen opgives: 1) Stilskriverens Navn og Alder, 2) Faderens (Moderens eller Husbondens) Navn og Bopæl, samt i hvilket Sogn Indsenderen hor.

Stilene sendes inden den 15. Januar 1906 til :

\section{Bornebladet}

Storegade 81 (Nerretorv)

Flensborg.

Stileopgave $i$ juleferien 1905-06.

ger man mere mærke til, at hvert nummer på sidste side havde gåder og lignende hovedbrud, som forudsatte et arbejde med sproget fra lasernes side.

Det siges lige ud af M. Andresen i bladet for 1893-94: "For skoleungdommen vil der herefter som hidindtil fra tid til anden blive stillet opgaver forbundne med præmieuddeling samt andre opgaver til skriftlig besvarelse, som kan tjene til støtte for hjemmeundervisningen i modersmålet. N Netop disse præmiestileopgaver er det, som er det sønderjyske børneblads særkende. Oprindelig blev opgaven udskrevet $\mathrm{i}$ april. Senere var det en fast regel, at der skulle skrives stil $\mathrm{i}$ juleferien. Undertiden var der en ekstra stileopgave $\mathrm{i}$ oktober for de sydligste dansktalende egne, Ābenrå, Flensborg og Tønder amter. Dette sidste ser ud som et særligt Flensborg Avis-træk, idet sproggrænsen og netop de nævnte områder havde avisens særlige interesse. Det gjaldt ved stileopgaverne at få alle med, og derfor var også afskrift tilladt, når den blot blev kendetegnet som sådan, ug alle, som sendte stile ind, fik præmie. Den bestod altid af brger, så at man fulgte den skriftlige syslen med sproget op med tilbud om en god bog at læse i. Det var studenterforeningen "Heimdal «s medlemmer, som samlede brgerne ind $\mathrm{i}$ kongeriget, og de rettede også stilene og sendte dem tilbage. I 1906 var der indsendt 1175 stile, $i$ 1907 «over tusind « efter bladets egne opgivelser og $i$ et brev fra 


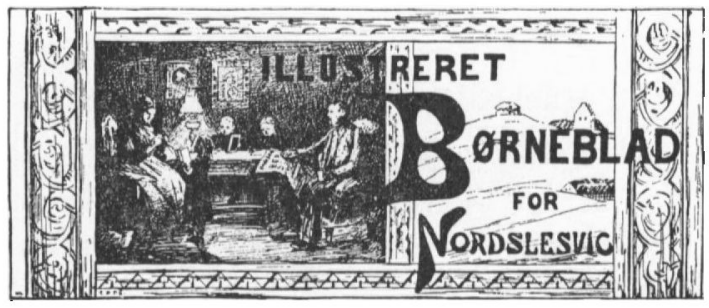

\begin{tabular}{ll}
\hline Nr. 21. 1 & Torsdag den 1. Augast 1901. \\
Faldne Mure.
\end{tabular}

II. Hjortholm.

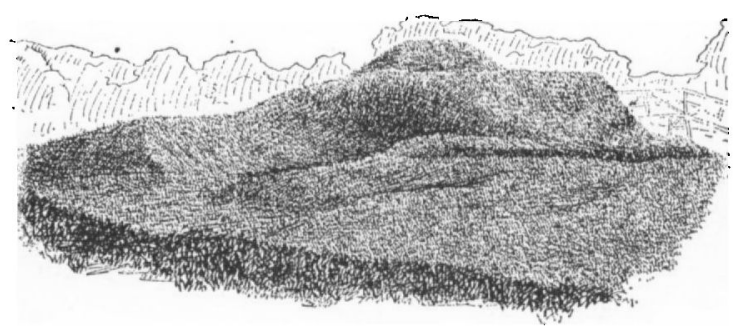

\begin{abstract}
Tet er en kendt Sag, at tandets Ud. - Som alle andre Saer liar Furnsoen ogsan seende forundrer sig i Tidens Lob: forandret sig; fur Aarlundreder siden Skoven ryddes, Heder ojdỵrkes, Soer var den meget storre end nu, og langy udtorres, og lbakke tilstephes; sauledes dens Bred viser store binge -ng Mosser hiclper Mennestiet Naturen med at ud- os, livortal Suens Herredumme forhen slette det gamle ug skabe njt i Sted't. strakte sig
\end{abstract}

Illustreret Borneblad for Nordslesvig 1. august 1901 med Vilhelm la Cours debutrakke „Faldne Mure. II. Hjortholm“.

»Heimdal « til redaktøren. ${ }^{4}$ I 1912-13 var det 2636, men dette tal er fra "Heimdal «s beretning, som også omfatter andre blade. ${ }^{5}$

Blandt stileskriverne lagde man mærke til enkelte børn, hvis evne til at udtrykke sig på modersmålet var usædvanlig. Blandt dem var et fattigt postbuds søn fra Flensborg, Ernst Christiansen, som blev Jens Jessens højre hånd og siden hans efterfølger. Også den anden navnkundige Jessen-lærling, A. Svensson, en skrædders søn fra Løjt Kirkeby, blev opdaget som stileskriver. Fra Ellund i Hanved sogn kom der en stil, der handlede om Uffe hin Spage i stedlig overlevering. Den var skrevet af Andreas Lorenzen, som fortsatte i dette spor og hele sit liv samlede folkeminder i Sydslesvig og udgav dem. Hans søn fortsætter børnebladets virksomhed som dansk lærer i Sydslesvig, hvoraf man kan se den langtrækkende virkning af børne- 
bladet, som nok kunne vises endnu tydeligere, hvis man gik grundigt til værks. Blandt bladets bidragydere var der en skoledreng fra Birkerød. Hans stykker hed "Faldne mure" og handlede blandt andet om borgen Hjortholm i Nordsjxlland. Tegningen dertil havde han selv gjort med hvert enkelt græsstrå tydeligt tegnet, hvad Thade Petersen fandt for udførligt gjort, hvortil kunstneren svarede, at det havde redaktøren ikke forstand på, og at det skulle være sådan. Det var den senere så kendte historiker og arkæolog Vilhelm la Cour, som trådte sine børnesko i "Illustreret Børneblad for Nordslesvig " og fik sine første 5 arkæologisk-historiske arbejder trykt fra juli 1901 til september 1902.

I det ydre var bladet især præget af billeder. Der var gengivelser af fotografier så gode, som tidens teknikere evnede det, men bladet var også gjort tiltalende ved mange fine tegninger af samtidens bedste kunstnere. Dog prægede tegninger mere bladet før 1905 end efter. Bladet har ved kvalitet og ved sin store udbredelse $i$ hele den danske presses område gjort en gerning for det danske sprogs liv $\mathrm{i}$ Sønderjylland, som ikke kan skattes højt nok. Især i den grå og triste krigstid har det været et lyspunkt $\mathrm{i}$ mange hjem, men som nævnt gik bladet ind i 1917.

I 1927 udkom det igen i Kolding under titlen Dansk Børneblad, men nu uden tilknytning til sønderjyske dagblade. Det holdt sig som et smukt blad med gode tegninger, til det gik ind i 1958. Som sin forgænger bragte det et fyldigt stof om Sønderjylland, ikke mindst om Sydslesvig.

\section{NOTER OG HENVISNINGER}

1. Kladde 16. marts -11 . september 1893. Landsarkivet, $\AA$ bentå.

2. N. Bang 6. januar 1903 til Jens Jessen. Flensborg Avis' arkiv i Dansk Centralbibliotek, Flensborg.

3. Breve 1904 fra Jens Jessen, A. Lebeck, H. Thomsen (Roost), M. Andresen og Konrad Jorgensen. Fl.A.ark. Ove Krarup: Koncepter til sønderjyske breve 1903-07. Flensborg Avis' arkiv. Mindeskrift om Konrad Jergensen. Ekstranummer af Højskolebladet 28. oktober 1921. Jens Jessens lommebog 1. maj23. november 1904. Landsarkivet, Ảbenrå. 16. oktober som tid for mødet på "Harmonien nævnes ikke $i$ brevene, men datoen er noteret af Jens Jessen $i$ lommebogen.

4. Esben Spang Hansen til L. P. Christensen 12. februar 1907. Fl.A.ark.

5. Studenterforeningen $>$ Heimdal«s Jubilæumsskrift 1896-1946. 